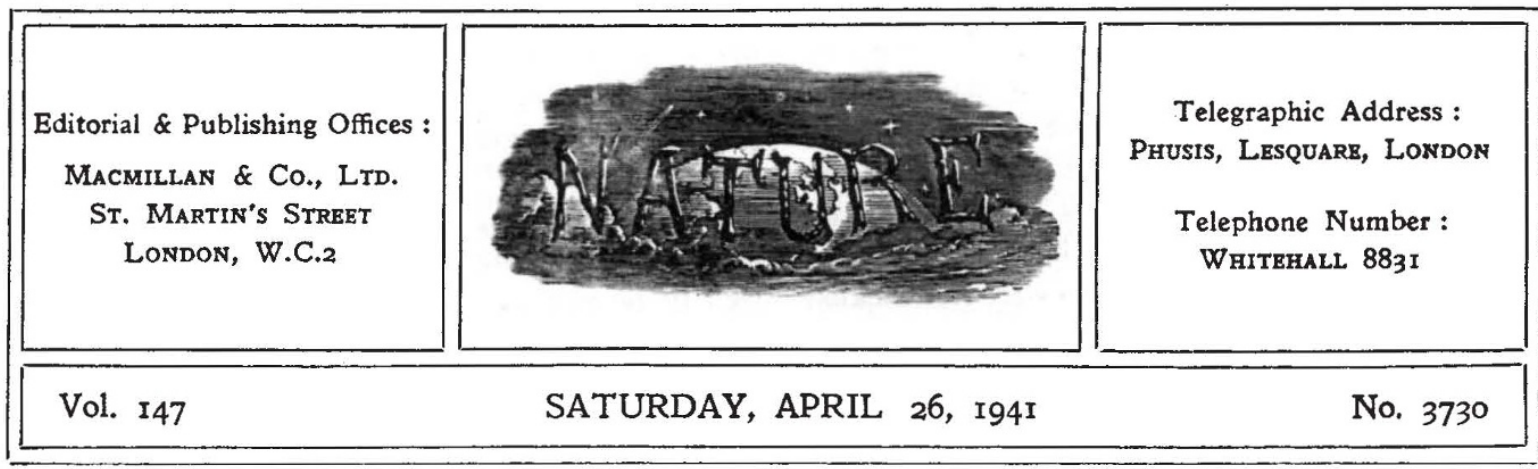

\title{
SCIENTIFIC ADMINISTRATION IN NATIONAL AND LOCAL GOVERNMENT
}

$\mathrm{T}$ HE attack on the Civil Service launched by Lord Percy in the House of Lords recently, is only one among many indications of disquiet about the efficiency of national administration in a democracy in times of peace as well as in the stress of war. It is not only from the national point of view, however, that the question of government and administrative efficiency is being raised anew. Just as in the national sphere we are being forced to consider the limitation of national sovereignty and even the transfer of certain powers to a federation if world order is to be established, so within the nation we are being forced to reconsider the units of local administration. The forces which in certain fields of public service were already making for regionalism have been powerfully reinforced by the exigencies of war. Under its influence and that of the regional organization developed for civil defence, the character of local government is being profoundly modified. Not only its efficiency but also its scope and character are coming in for reconsideration and development.

These circumstances give pertinence to a number of studies of public undertakings which have appeared in recent years. We have had, for example, "Public Enterprise", a series of studies of developments in social ownership and control in Great Britain, covering the Port of London Authority, the Forestry Commission, the British Broadcasting Corporation, the Central Electricity Board, the London Passenger Transport Board, the Post Office, and others, edited for the New Fabian Record Bureau by Dr. W. A. Robson. Mr. T. H. O'Brien's “British Experiments in Public Ownership and Control" is one of a new series of studies under a recent scheme promoted by the Institute of Public Administration, and confines itself to the Central Electricity Board, the British Broadcasting Corporation and the London Passenger Transport Board. Dr. W. A. Robson's "The Government and Misgovernment of London" is a further important contribution, while still more recently, in "Advisory Bodies : a Study of their Uses in Relation to Central Government", by the Oxford University Politics Research Group, we have a careful examination of an instrument to which much importance was attached by Lord Haldane in the Machinery of Government Report.

One of the most difficult questions, and one which is at the same time closely related to the problems of regionalism, is that of municipal trading, examined by Dr. Herman Finer in a recently published volume.* Concentrating his attention on the four main municipal undertakings-electricity, gas, transport and water-he discusses the various theoretical problems raised by municipal enterprise, a brief survey of the historical development of municipal trading being followed by an account of the legal framework.

The main interest of this study at the present time lies in those parts of the second book, concerned with factors in production, which deal with administrative organization and personnel and with the size of the undertaking, and in the concluding observations on the balance of deterrents from, and incentives to, efficiency, and the factors of success and their development which comprise the fourth book.

Dr. Finer's principal criticism of the administrative organization relates to the size of the managing committees. The large membership

* Municipal Trading: a Study in Public Administration. By Dr. Herman Finer. Pp. 432. (London: George Allen and Unwin, Ltd., 1941.) 168. net. 
is required because the committees in charge of undertakings are representative of the council, and the council representative of the electorate is not conducive to a high degree of responsibility. Control of public enterprise tends to be anticipatory, to avoid the errors which have been seen to occur in private enterprise. On the other hand, it is recognized that the greatest single decision which a committee ean make is the choice of its technical chief. Upon his expertness, and, just as much upon his character as an administrator and vision as a business man, the solvency and service of the undertaking depend; and generally speaking the committee is regarded as responsible for policy, while the manager is responsible for administration and is given a free hand in the planning of development and the execution of policy.

The conclusion is reached that, with few exceptions, municipal undertakings in Great Britain are efficiently administered, but while the weak spot of anticipatory control is referred to, insufficient stress is placed upon the extent to which conditions to-day are demanding a more dynamic and creative type of administration. These demands are made both in the field of policy and in that of day-to-day administration, and the extent to which war conditions have revealed the shortcomings of those, who are merely capable of routine administration, only accentuates a weakness which was already becoming apparent in local and national administration in time of peace. It will no longer be sufficient for municipal undertakings to demonstrate their capacity for routine administration. They must show now that they also possess wide vision and powers of innovation and creative developmentthe power to see the services for which they are responsible in terms of wider national needs, and the capacity to judge between conflicting views of the public interest in those services.

It is the great merit of studies of the character of Dr. Finer's survey that they bring to light inherent weaknesses and facilitate the provision of correctives. The healthiest single factor in the success of municipal undertakings, he points out, has been direct democratic control, and for this reason he would deprecate any reorganization of these utilities on the lines of the semi-public corporation, of which he is severely critical, owing to its remoteness from control by the consumer. The development of that task of adult education in citizenship, and particularly in the functioning of, and application of, democratic methods upon which the continuance of genuine and efficient local government really depends, is calculated in itself to stimulate the provision of both a better type of councillor and committee man, and the supply of officials of the highest administrative capacity.

The technical officers are of critical importance. They, after all, are members of a profession, and for all save the very exceptional men will be limited by the general standard of their profession, just as that standard from another point of view ensures the maintenance of a high standard of efficiency. It is a welcome sign that professional men are increasingly taking an interest in the wider horizons of their profession and in the relation to post-war reconstruction, as indicated by Sir John Orr's address to the British Medical Association, Prof. A. V. Hill's address to the Parliamentary and Scientific Committee (see Nature, March 1, p. 250), and Dr. John V. N. Dorr's address as Perkin medallist of the Society of Chemical Industry on the engineer and his responsibilities to the world of to-day and to-morrow.

It is only as the scientific worker and other professional men no longer content themselves with the easy task of criticizing the routine and timidity of civil service administration, but accept their own wider responsibilities and attempt to make positive contributions to the development of administrators characterized by creative ability and the capacity to promote energetic and farreaching projects, and seeing opportunities rather than difficulties, that we can hope for advance. The administrator, whatever his professional origin, who is to use his opportunities to the full and carry with him those whose vision is narrower and who are less willing to co-operate or to take risks, needs not only the assurance of professional tradition but also the inspiration of professional ideals. Much might yet be done, even in its present form, to raise the outlook and character of local government and administration and to stimulate co-ordination, regionalism and the reorganization of areas, if the technical officers in municipal undertakings had the support of a wide and generous outlook and understanding from their professional associations.

Among the suggestions which Dr. Finer advances for improvement in the efficiency of municipal enterprise is steadfast and determined attention to the selection of officers of all grades. He advocates a much severer probation, and that technical officers as well as the administrative and clerical staffs should be compelled to take some such course as that prescribed for the diploma of public 
administration instituted at various universities. Those managing undertakings must learn to appreciate their strength, and also the weaknesses against which they must continually pit their determination, so that they may be equal to the even severer demands which the necessary coordination and reorganization of areas will involve.

The possibilities of interchange of staff mentioned by Prof. A. V. Hill in his address referred to above, should also be given serious consideration. If we could once more stimulate the exchange and movement of technical and scientific workers between Government departments, local authorities, the universities and industry itself, the advantages in creative work as well as administrative outlook and efficiency would be far-reaching, from the scientific, technical, social and national point of view. The value of thus stimulating creative thought and checking departmentalism should make well worth while the effort required to develop a uniform pensions scheme, calculated to assist and encourage mobility whether between Government departments, the local government services, the universities or even industry. Even if the attempt can only be made over a part of the field, co-operation between Government service and the universities as suggested by Prof. Hill is a promising line of advance. Moreover, the wider experience and outlook which flow from increased mobility should assist to throw up administrators of the type so urgently required. Local government services have in fact done little to implement the findings of the Hadow Committee, nor have such public corporations as the British Broadcasting Corporation, the London Passenger Transport Board or the Central Electricity Board realized the possibilities which are before them of handling staff problems so as to develop an administrative service free from even the defects for which the Civil Service has been criticized.

\section{FORESTRY ADMINISTRATION}

\section{Colonial Forest Administration}

By Prof. R. S. Troup. Pp. xii $+476+32$ plates. (London: Oxford University Press, 1940.) 35s. net.

FORESTERS throughout the Empire will be glad to learn through the publication of this book that Prof. Troup was just able to complete this important work, which it was generally known he had in hand, before being struck down by the illness which proved fatal; from the prefatory note we learn that it fell to Mrs. Troup and Prof. H. M. Steven to see it through the press. One can confidently say that no one, but Troup with his exceptionally wide experience and clarity of thought and expression, could have written it. For both presentation of subject and printing we have nothing but praise, and do not remember ever having read through a book of 450 pages on forestry which revealed so few points calling for criticism. There may be, however, one rather fundamental doubt about it, and that is whether, in view of the public for which the book is stated to be written, namely, probationers and officers of the Colonial Administrative Service, it is not too lengthy and too expensive. The cost and length will, we believe, prevent its purchase by a large number of potential readers who would find it of great interest and value; it is too good a book to be referred to occasionally in the library, and but for these diffculties should surely find a place on the private bookshelf of all foresters and others interested in forestry.

The preface explains how the subject-matter of a short course of lectures has come to be expanded to so solid a volume, but we feel that a significant amount of the more technical aspects of forestry, such as a discussion of the mean and current annual increment and details of working-plan procedure, could have been omitted, though their inclusion undoubtedly results in the presentation to the administrator of a more finished picture of forestry in general. As it is, it can confidently be asserted that no colonial administrator or forester can read the book without finding a great deal of useful information new to him, whilst some of the surveys such as those on the effects of forest destruction and on the character and distribution of forests are masterpieces of skilful compression; the explanation of a working plan and sylvicultural systems is equally good. The book as a whole also answers extremely well the common query: "What does a forester do ?"

The book is divided into two parts. Part 1 deals on broad lines with all the major heads of forestry, such as the influence of forest on climate, soil erosion, the effects of forest destruction and measures for protection, forest reservation, State control, etc. Part 2 takes the units of the Colonial Empire in turn and describes the major points of policy and administration in each. 